\title{
THE INFLUENCE OF COOPERATIVE LEARNING BASED ON THE VAN HIELE THEORY TOWARD PROBLEM SOLVING ABILITY ON GEOMETRY OF MATHEMATICS EDUCATION STUDENTS
}

\author{
Hera Deswita ${ }^{1}$, Nurrahmawati² \\ 1,2Universitas Pasir Pengaraian \\ heraiwit18@gmail.com
}

\begin{abstract}
One of the mathematical problems whose solution requires the problem solving ability is geometry. Van Hiele's Theory is a learning solution that can be applied to practice the problem solving ability of geometry. Van Hiele states that the 5 levels of geometry thinking are the stages of introduction, analysis, sequencing, deduction and accuracy. The purpose of this study was to determine whether or not the influence of Van Hiele's theory-based cooperative learning on the geometrical problem solving abilities of students of Mathematics Education at Pasir Pengaraian University on space geometry. This study uses a quasi-experimental method with the design of Two Group Posttest Only. The population in this study were students of mathematics education at the Pasir Pengaraian University. The technique used for sampling is saturated samples, namely fifth semester students taking three-dimentional geometry. The instrument used was a test of problem solving ability. Data analysis using t-test. The results showed that the acquisition value of sig $0.001<0.05$. Thus it can be concluded that there is an influence of Van Hiele's theory-based cooperative learning on the ability of problem solving geometry of students of Mathematics Education at Pasir Pengaraian University on space geometry.
\end{abstract}

Kata-kata Kunci: Van Hiele theory, Problem Solving ability, space geometry.

\begin{abstract}
ABSTRAK Salah satu masalah matematika yang penyelesaiannya membutuhkan kemampuan pemecahan masalah adalah geometri. Teori Van Hiele merupakan solusi pembelajaran yang dapat diterapkan untuk melatih kemampuan pemecahan masalah geometri. Van Hiele menyatakan bahwa 5 level berpikir geometri yaitu tahap pengenalan, analisis, pengurutan, deduksi dan keakuratan. Tujuan penelitian ini adalah untuk mengetahui ada atau tidak pengaruh pembelajaran kooperatif berbasis teori Van Hiele terhadap kemampuan pemecahan masalah geometri mahasiswa Pendidikan Matematika Universitas Pasir Pengaraian pada materi bangun ruang. Penelitian ini menggunakan metode quasi eksperimen dengan rancangan Two Group Posttest Only. Populasi pada penelitian ini adalah mahasiswa Pendidikan matematika Universitas pasir Pengaraian. Teknik yang digunakan untuk pengambilan sampel adalah sampel jenuh yaitu mahasiswa semester lima yang mengambil matakuliah geometri ruang. Instrumen yang digunakan adalah tes kemampuan pemecahan masalah. Analisis data menggunakan uji-t. Hasil penelitian menunjukkan bahwa perolehan nilai sig $0.001<0.05$. Dengan demikian dapat disimpulkan bahwa ada pengaruh pembelajaran kooperatif berbasis teori Van Hiele terhadap kemampuan pemecahan masalah geometri mahasiswa Pendidikan Matematika Universitas Pasir Pengaraian pada materi bangun ruang.
\end{abstract}

Kata-kata Kunci: Teori Van Hiele, Kemampuan Pemecahan Masalah, Geometri Ruang 


\section{PENDAHULUAN}

Salah satu keterampilan yang harus dimiliki oleh mahasiswa dalam menghadapi tantangan global di abad 21, baik masalah di bidang ekonomi, kesehatan, sosial dan pendidikan adalah kemampuan pemecahan masalah. Kemampuan pemecahan masalah adalah kemampuan memahami masalah, merencanakan strategi dan melaksanakan rencana pemecahan masalah. keterampilan pemecahan masalah dapat membantu mahasiswa dalam menyelesaikan berbagai permasalahan yang akan dihadapai dalam kehidupan sehati-hari.

Sebagai calon guru matematika mahasiswa dituntut agar nantinya ketika mengajar dapat mengembangkan kemampuan pemecahan masalah bagi siswa di sekolah. Hal ini disebabkan oleh kenyataan bahwa kemampuan pemecahan masalah siswa Indonesia masih rendah. Hal ini dibuktikan oleh hasil studi TIMSS (Trend In International Mathematics And Science Study) 2015 yang baru dipublikasikan Desember 2016 lalu menunjukkan prestasi siswa Indonesia bidang matematika mendapat peringkat 46 dari 51. Selain itu juga menunjukkan bahwa Indonesia berada pada rangking 36 dari 49 negara dalam hal melakukan prosedur ilmiah. TIMSS memaparkan bahwa penekanan pembelajaran matematika di Indonesia lebih banyak pada penguasaan keterampilan dasar, hanya sedikit sekali pada penekanan penerapan dalam konteks kehidupan sehari-hari. Fakta tersebut membuktikan bahwa tujuan pembelajaran matematika belum tercapai, yang salah satu adalah menumbuhkan kemampuan pemecahan masalah. Dengan demikian mahasiswa calon guru matematika dituntut memiliki kemampuan pemecahan masalah sebelum mengajar matematika di sekolah.

Beberapa penelitian menunjukkan bahwa kemampuan pemecahan masalah matematika mahasiswa masih rendah. Penelitian yang dilakukan Kurniawan (2015: 67-73) menyimpulkan bahwa keterampilan pemecahan masalah mahasiswa masih rendah. Proses pemecahan masalah yang meliputi: identifikasi soal dan materi prasyarat, penyusunan rencana penyelesaian, dan mengevaluasi hasil dan rencana penyelesaian belum dilaksanakan oleh mahasiswa. Kenyataan ini hampir sama dengan hasil penelitian Rahmatina (2016: 294) yang menyimpulkan bahwa mahasiswa belum sepenuhnya bisa mengkomunikasikan kemampuan matematisnya dalam pemecahan masalah bangun ruang sisi lengkung, walaupun soal yang diberikan merupakan soal matematika untuk SMP kelas IX, namun ternyata mahasiswa belum mampu menjawab semua soal dengan tepat. Beberapa kesulitan yang dihadapi mahasiswa dalam menyelesaikan soal pemecahan masalah bangun ruang sisi lengkung diantaranya: mahasiswa tidak memahami maksud pada gambar yang diberikan sehingga mangalami kesulitan dalam mengkomunikasikan konsep matematis dalam pemecahan masalah geometri dan kesulitan lainnya yaitu menentukan rumus yang akan digunakan karena ada bangun di dalam bangun ruang.

Berdasarkan hasil dari beberapa penelitian tersebut maka perlu menemukan solusi untuk melatih kemampuan pemecahan masalah mahasiswa. Salah satu materi matematika yang membutuhkan kemampuan pemecahan masalah adalah geometri. Geometri merupakan cabang matematika yang dipelajari di semua 
jenjang pendidikan baik pendidikan sekolah dasar sampai sekolah menengah atas maupun kejuruan seperti teknik dan tata boga. Benda-benda visual yang berkaitan dengan geometri dapat kita temui dalam kehidupan sehari-hari diantaranya piramida, rumah, bak mandi, kolam, sawah dan drum dan lain sebagainya. Mahasiswa sebaiknya dilatih untuk menyelesaikan permasalahan tersebut karena sering muncul dalam keseharian. Permasalahan tersebut misalnya adalah berapa besar tangki yang dibutuhkan untuk mengisi air dengan debit dan waktu yang diketahui.

Sebagai calon guru matematika mahasiswa diharapkan mampu dan terlatih dalam menghadapi berbagai masalah bidang geometri khususnya bangun ruang. Salah satu cara ynag dapat dilakukan adalah dengan menerapkan pembelajaran kooperatif. Penerapan Pembelajaran kooperatif dapat melatih mahasiswa bekerjasama dalam memecahkan masalah yang akan diberikan. Dalam penerapannya setiap kelompok akan mempelajari modul dan dilengkapi dengan soal pemecahan masalah yang harus diselesaikan bersama. Untuk menstimulasi agar mahasiswa menjadi pemecah masalah yang baik, NCTM (1989) menganjurkan agar pembelajaran memberikan kesempatan agar mahasiwa

1. Dapat membangun pengetahuan matematis baru melalui pemecahan masalah

2. Memecahkan masalah baik yang terdapat dalam matematika maupun konteks lain

3. Menerapkan berbagai strategi yang cocok dalam memecahkan masalah

4. Memonitor dan melakukan refleksi terhadap proses-proses yang dilakukan dalam memacahkan masalah-masalah matematika.

Salah satu teori yang dapat diterapkan untuk mendukung peningkatan keterampilan tersebut adalah Teori Van Hiele. Menurut Safrina (2014: 10) teori ini menjelaskan bahwa dalam mempelajari geometri, mahasiswa akan melalui tingkatan berpikir yang berurutan yaitu pengenalan, pengurutan, dedukasi dan akurasi. Musa (2016:107) menggambarkan bahwa objek (ide-ide) dari level teori Van Hiele tentang berpikir geometri lebih rinci dapat dilihat pada gambar 1 berikut.

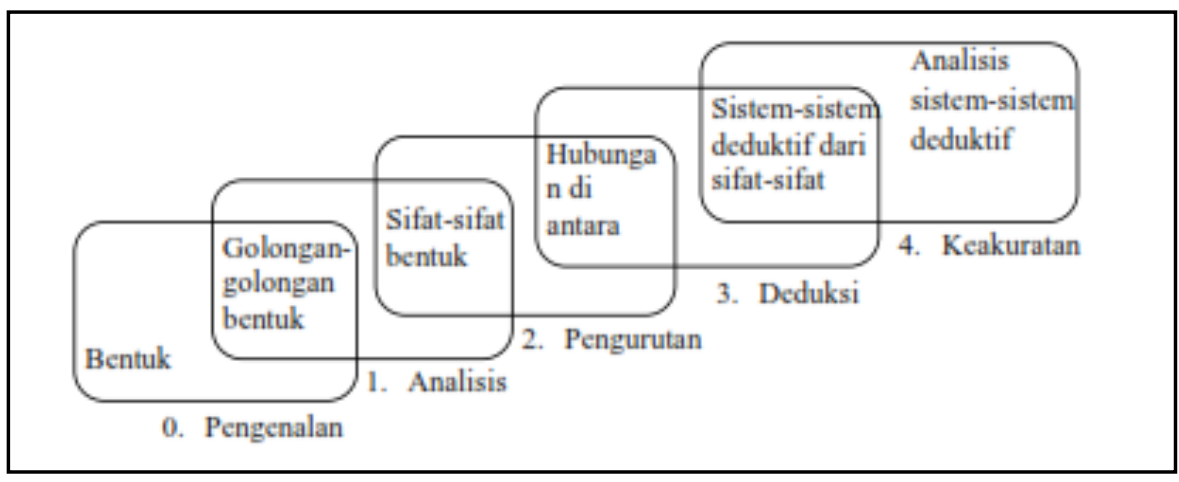

\section{Gambar 1. Objek/Ide-ide dari Teori van Hiele}

Proses berpikir yang demikian akan melatih siswa agar sistematis dalam memecahkan masalah dan berpikir agar memperoleh hasil yang diharapkan. Piere van Hiele dan Dina van Hiele-Geldof (Usiskin, 1982) mengusulkan tahap-tahap belajar 
dalam geometri berbasis teori van Hiele diterapkan secara berurutan yaitu tahap informasi, orientasi terarah, eksplisitasi, orientasi bebas, dan integrasi.

Penerapan tahapan tersebut dalam perkuliahan dapat dilakukan sebagai berikut. 1) Tahap Inquiri/ tahap informasi merupakan tahap awal yang diisi dengan kegiatan tanya jawab antara dosen dan mahasiswa mengenai objek-objek yang dipelajari pada tingkat analisis. Kegiatan ini bertujuan untuk mengetahui pengetahuan awal mahasiswa mengenai topik yang akan dipelajari serta mendata mahasiswa sesuai dengan tingkat berpikirnya. 2) Tahap orientasi terarah, merupakan tahap kedua yang dilakukan dalam pembelajaran berbasis teori van Hiele. Pada tahap ini, mahasiswa diarahkan untuk mengamati karakteristik khusus dari objek-objek yang dipelajari melalui tugas yang diberikan dosen. 3)Tahap penjelasan, merupakan lanjutan dari tahap sebelumnya. Pada tahap ini, mahasiswa diarahkan agar dapat menyatakan pandangan mereka yang muncul mengenai hubungan konsep-konsep geometri yang telah dikaji dengan bahasa mereka sendiri (misalnya mengenai sifatsifat dari bangun geometri yang diamati). 4) Tahap orientasi bebas, pada tahap ini mahasiswa dihadapkan pada tugas-tugas yang lebih kompleks berupa tugas yang dapat diselesaikan dengan banyak cara dan memerlukan banyak langkah. Misalnya mahasiswa ditugaskan untuk membuat memecahkan masalah geometri yang lebih kompleks. 5) Tahap integrasi, pada tahap ini mahasiswa meringkas dan menyimpulkan apa yang telah mereka pelajari dengan membuat hubungan antara objek-objek geometri yang diamati.

Dengan demikian perlu dilakukan penelitian apakah pembelajaran teori van hiele ini dapat mempengaruhi kemampuan pemecahan masalah matematika mahasiswa pendidikan matematika. Tujuan penelitian ini adalah untuk mengetahui pengaruh pembelajaran kooperatif berbasis teori Van Hiele terhadap kemampuan pemecahan masalah geometri mahasiswa Pendidikan Matematika Universitas Pasir Pengaraian pada materi bangun ruang.

\section{METODE PENELITIAN}

Penelitian ini adalah penelitian eksperimen yang termasuk dalam eksperimen semu dengan menggunakan rancangan Two Group Posttest Only. Populasi di dalam penelitian adalah seluruh mahasiswa Semester ganjil Program studi Pendidikan matematika FKIP UPP. Sampel yang digunakan pada penelitian ini adalah seluruh mahasiswa semester 5 (lima) Pendidikan matematika FKIP UPP yang terdiri dari 2 kelas. Kepada kedua kelas dilakukan uji normalitas dan homogenitas varians. Hasil uji tersebut menyatakan bahwa kedua kelas normal dan homogen sehingga teknik pengambilan sampel menggunakan sampel jenuh dapat dilakukan. Instrumen dalam penelitian ini meliputi instrumen soal pemecahan masalah untuk mengukur kemampuan pemecahan masalah geometri mahasiswa. Teknik yang digunakan dalam memperoleh data penelitian adalah tes. Tes dilakukan diakhir penelitian setelah diterapkan pembelajaran kooperatif berbasis teori Van Hiele. Tes yang telah dilaksanakan dinilai dengan menggunakan pedoman penskoran. Pedoman penskoran yang digunakan pada penelitian ini mengacu pada penskoran Charles, R., Lester, F., \& O'Daffer, P, dan Holistic Rubric Scoring dan dimodifikasi dari rubric 
penskoran yang digunakan oleh Isharyadi ( 2015: 37). Pedoman penskoran untuk tes kemampuan pemecahan masalah matematis tersebut adalah sebagai berikut.

Tabel 1 . Pedoman Penskoran Kemampuan Pemecahan Masalah Matematis

\begin{tabular}{cl}
\hline Skor & \multicolumn{1}{c}{ Kriteria } \\
\hline 4 & $\begin{array}{l}\text { Jawaban benar dan semua aspek pemecahan } \\
\text { masalah matematis dijawab dengan jelas dan } \\
\text { lengkap }\end{array}$ \\
\hline 3 & $\begin{array}{l}\text { Menerapkan strategi penyelesaian yang benar, } \\
\text { namun hanya sebagian aspek pemecahan } \\
\text { masalah matematika yang dijawab dengan benar }\end{array}$ \\
\hline 2 & $\begin{array}{l}\text { Memiliki rencana penyelesaian masalah yang } \\
\text { mengarah pada solusi apabila diterapkan dengan } \\
\text { benar }\end{array}$ \\
\hline 1 & $\begin{array}{l}\text { Memahami masalah, namun tidak memiliki rencana } \\
\text { penyelesaian yang jelas }\end{array}$ \\
\hline 0 & $\begin{array}{l}\text { Tidak memahami masalah sama sekali/ tidak ada } \\
\text { jawaban }\end{array}$ \\
\hline
\end{tabular}

Analisis data dilakukan dengan uji- $\dagger$ yaitu independent sample t-test. Sebelum melakukan uji hipotesis maka dilakukan uji normalitas dengan menggunakan uji Kolmogorof-Smirnov dan uji homogenitas dengan menggunakan uji levene. Seluruh proses analisis data dibantu dan memanfaatkan aplikasi program komputer SPSS 18.0 for Windows.

\section{HASIL DAN PEMBAHASAN}

Data hasil penelitian yang dideskripsikan adalah data post-test tentang kemampuan pemecahan masalah matematis mahasiswa yang diajarkan dengan pembelajaran kooperatif berbasis teori Van Hiele dan pembelajaran konvensional pada mata kuliah geometri ruang. Hasil analisis skor post-test kemampuan pemecahan masalah matematis dapat dilihat pada Tabel 2 berikut

Tabel 2. Hasil Analisis Skor Post-test Kemampuan Pemecahan Masalah Matematis

\begin{tabular}{ccccccc}
\hline Kelas & $\mathbf{N}$ & $\overline{\boldsymbol{x}}$ & $\boldsymbol{S}$ & $\boldsymbol{S}^{\mathbf{2}}$ & $\mathbf{X}_{\max }$ & $\mathbf{X}_{\min }$ \\
\hline Eksperimen & 26 & 66,539 & 16,719 & 279,538 & 95 & 30 \\
\hline Kontrol & 22 & 49,091 & 15,325 & 234,848 & 75 & 20
\end{tabular}

Uji normalitas kedua data Kemampuan Pemecahan Masalah Matematis Mahasiswa dilakukan menggunakan uji statistik one-sample Kolmogorov-Smirnov. Kriteria pengujian yang digunakan adalah jika nilai $p$-value (Sig.) lebih besar dari nilai $\alpha=$ 0.05, maka terima Ho. Berikut hipotesis pengujiannya:

Ho: kemampuan pemecahan masalah matematis mahasiswa berdistribusi normal

$\mathrm{H}_{1}$ : kemampuan pemecahan masalah matematis mahasiswa tidak berdistribusi normal 
Hasil uji normalitas distribusi data kemampuan pemecahan masalah matematis mahasiswa kelas eksperimen dan kelas kontrol dapat dilihat pada Tabel 3 berikut.

Tabel 3. Hasil Uji Normalitas Distribusi Data Kemampuan Pemecahan Masalah Matematis Mahasiswa

\begin{tabular}{llll}
\hline Kelas & Kormogorov-Sminov Z & Sig. & Kesimpulan \\
\hline Eksperimen & .156 & .106 & Terima $\mathrm{H}_{0}$ \\
\hline Kontrol & .115 & .200 & Terima $\mathrm{H}_{0}$ \\
\hline
\end{tabular}

Pada Tabel 3 terlihat bahwa kemampuan pemecahan masalah matematis mahasiswa kelas eksperimen dan kelas kontrol mempunyai nilai Sig. lebih besar dari taraf nyata $(\alpha=0,05)$, hal ini berarti bahwa terima $H_{0}$. Dengan demikian dapat disimpulkan bahwa kemampuan pemecahan masalah matematis mahasiswa pada kelas eksperimen dan kelas kontrol berdistribusi normal.

Setalah uji normalitas dilakukan uji homogenitas kedua varians. Uji homogenitas dilakukan untuk mengetahui apakah variansi data post-test kedua kelas homogen atau tidak. Kriteria pengujian yang digunakan adalah jika nilai $p$-value (Sig.) lebih besar dari nilai $\alpha=0.05$, maka terima $\mathrm{H}_{0}$.

Hasil perhitungan uji homogenitas data post-test kemampuan pemecahan masalah matematis dapat dilihat pada Tabel 4 berikut.

Tabel 4. Hasil Uji Homogenitas Variansi Data Kemampuan Pemecahan Masalah Matematis Mahasiswa Pendidikan Matematika UPP

\begin{tabular}{lllll}
\hline Levene Statistic & df1 & df2 & Sig. & Kesimpulan \\
\hline 0.001 & 1 & 46 & 0.970 & Terima $\mathrm{H}_{\circ}$ \\
\hline
\end{tabular}

Berdasarkan hasil perhitungan pada Tabel 4 di atas, terlihat bahwa nilai signifikansi data kemampuan pemecahan masalah matematis mahasiswa adalah 0.970 . Karena nilai signifikansinya lebih besar dari taraf signifikansi $\alpha=0.05$, maka kesimpulan yang diperoleh adalah terima $\mathrm{H}_{0}$, artinya data kemampuan pemecahan masalah matematis kedua kelas, yaitu kelas eksperimen dan kelas kontrol memiliki varians yang homogen.

Berdasarkan uji normalitas dan uji homogenitas pada kedua kelas sampel diketahui bahwa data kemampuan pemecahan masalah matematis mahasiswa berdistribusi normal dan memiliki variansi yang homogen maka selanjutnya dilakukan uji $\dagger$ untuk menguji hipotesis penelitian. Kriteria pengujian yang digunakan adalah jika nilai pvalue (Sig.) lebih besar dari nilai $\alpha=0.05$, maka terima $\mathrm{H}_{0}$. Berikut hipotesis statistiknya:

$\mathrm{H}_{0}: \mu_{1}=\mu_{2}$

$\mathrm{H}_{1}: \mu_{1} \neq \mu_{2}$

Hipotesis yang diuji adalah: 
$\mathrm{H}_{0}$ : Tidak ada pengaruh pembelajaran kooperatif berbasis teori Van Hiele terhadap kemampuan pemecahan masalah geometri mahasiswa pendidikan matematika Universitas Pasir Pengaraian

$\mathrm{H}_{1}$ : Ada pengaruh pembelajaran kooperatif berbasis teori Van Hiele terhadap kemampuan pemecahan masalah geometri mahasiswa pendidikan matematika Universitas Pasir Pengaraian

hasilnya dapat dilihat pada tabel 5 berikut.

Tabel 5. Hasil Uji Kesamaan Rata-rata Kemampuan Pemecahan masalah atematis Mahasiswa Pendidikan Matematika UPP

\begin{tabular}{lccclll|}
\hline Kelas & $\mathbf{N}$ & Rerata & $\begin{array}{l}\text { Standar } \\
\text { Deviasi }\end{array}$ & $\begin{array}{l}\text { Sig. } \\
\text { (2-tailed) }\end{array}$ & $\begin{array}{l}\text { Sig. } \\
\text { (1-tailed) }\end{array}$ & $\begin{array}{l}\text { Simpula } \\
\mathbf{n}\end{array}$ \\
\cline { 1 - 6 } Eksperimen & 26 & 66.539 & 16.719 & 0.001 & 0.0005 & Tolak Ho \\
\cline { 1 - 5 } Kontrol & 22 & 49.091 & 15.325 & & & \\
\hline
\end{tabular}

Berdasarkan Tabel 5 di atas, nilai signifikansi (1-tailed) yang diperoleh adalah 0,0005. Nilai signifikansi tersebut lebih rendah daripada taraf signifikansi $\alpha=0.05$, sehingga kesimpulan yang diperoleh adalah tolak Ho. Artinya, ada pengaruh pembelajaran kooperatif berbasis teori Van Hiele terhadap kemampuan pemecahan masalah geometri mahasiswa pendidikan matematika Universitas Pasir Pengaraian

Hasil pengujian hipotesis terhadap data kemampuan pemecahan masalah matematis mahasiswa menunjukkan bahwa terdapat pengaruh model pembelajaran kooperatif berbasis teori Van Hiele terhadap kemampuan pemecahan masalah geometri mahasiswa pendidikan matematika Universitas Pasir Pengaraian. Berdasarkan data yang diperoleh dari kedua kelas sampel, rata-rata nilai mahasiswa dikelas eksperimen lebih tinggi dari rata-rata nilai mahasiswa di kelas kontrol.

Penyebab rata-rata nilai kelas eksperimen lebih tinggi daripada rata-rata nilai kelas kontrol karena kelas ekperimen diberi perlakuan dengan menerapkan model pembelajaran kooperatif berbasis teori Van Hiele. Pembelajaran kooperatif memberikan kesempatan kepada mahasiswa untuk belajar bersama dalam kelompok untuk memahami konsep matematika dengan lebih menyenangkan sesuai dengan penjelasan Slavin (2009:100) yang menyatakan bahwa pembelajaran kooperatif bukan hanya sebuah teknik pengajaran yang ditujukan untuk meningkatkan pencapaian prestasi para siswa, ini juga merupakan cara untuk menciptakan keceriaan, lingkungan yang pro-sosial di dalam kelas, yang merupakan salah satu manfaat penting untuk memperluas perkembangan interpersonal dan keefektifan. Setiap mahasiswa memiliki kemampuan yang berbeda-beda, ada yang berkemamuan tinggi, sedang dan rendah. Pembelajaran berkelompok membuat mahasiswa bebas untuk bertanya dan berdiskusi dengan teman sebaya terhadap 
konsep yang belum dipahami. Adakalanya seseorang lebih paham jika suatu konsep dijelaskan oleh teman dari pada penjelasan guru.

Penerapan teori Van Hiele sangat berpengaruh terhadap pemahaman mahasiswa pada materi geometri. Pembelajaran berdasarkan teori van Hiele ini memiliki tahapan-tahapan yang sesuai dengan karakteristik geometri. Dalam pembelajaran geometri membutuhkan strategi yang tepat agar pemahaman mahasiswa dalam mempelajari geometri lebih sistematis dan hirarki. Van Hiele menjelaskan tahaptahap atau perkembangan mental siswa dalam memahami Dengan demikian teori Van Hiele sangat cocok diterapkan dalam pembelajaran geometri dari sekolah tingkat dasar hingga pergurvan tinggi.

\section{KESIMPULAN DAN SARAN}

Berdasarkan uji hipotesis maka dapat disimpulkan bahwa ada pengaruh pembelajaran kooperatif berbasis teori Van Hiele terhadap kemampuan pemecahan masalah geometri mahasiswa pendidikan matematika Universitas Pasir Pengaraian.

Pembelajaran berbasis teori van hiele ini dapat dijadikan sebagai salah satu alternative bagi pengajar baik guru maupun dosen dalam pembalajaran matematika khususnya geometri.

\section{UCAPAN TERIMAKASIH}

Terimakasih kepada Kemenristek Dikti yang telah memberikan dana hibah penelitian sehingga penelitian ini dapat dilakukan dengan baik.

\section{DAFTAR PUSTAKA}

Isharyadi, Ratri. 2015. "Pengaruh Penerapan Pendekatan Kontekstual Terhadap Peningkatan Kemampuan Pemecahan Masalah dan Beliefs Matematis Siswa SMP". Tesis. Bandung: UPI

Kurniawan. 2015. Analisis Keterampilan Pemecahan Masalah Pada Pembelajaran Matematika. Prosiding Seminar Nasional Pendidikan : 67-73.

Musa. 2016. Level Berpikir Geometri Menurut Teori Van Hiele Berdasarkan Kemampuan Geometri dan Perbedaan Gender Siswa Kelas VII SMPN 8 ParePare. Jurnal Pendidikan Matematika dan Ilmu Pengetahuan Alam, 4(2):103116.

NCTM. 2000. Curriculum and Evaluation Standards for School Mathematics. Reston VA: Authur.

Rahmatina. 2016. Analisis Kemampuan Komunikasi Matematis Calon Guru Matematika Dalam Pemecahan Masalah Bangun Ruang Sisi Lengkung. Prosiding Seminar Nasional Matematika Dan Pendidikan Matematika: 287294. 
Safrina, Khusnul dkk. 2014. Peningkatan Kemampuan Pemecahan Masalah Geometri melalui Pembelajaran Kooperatif Berbasis Teori Van Hiele. Jurnal Didaktik Matematika. Vol. 1, No. 1 : 9-20.

Slavin, Robert E. 2009. Cooperative Learning. Bandung: Nusa Media. 